\title{
1 Analysis of Trade-offs between Food Security and Water-Land 2 Savings through Food Trade and Structural Changes of Virtual 3 Water Trade in the Arab World
}

\author{
4 Sang-Hyun Lee ${ }^{1}$, Rabi H. Mohtar ${ }^{1}$, Seung-Hwan Yoo ${ }^{2}$ \\ $5 \quad{ }^{1}$ Department of Biological and Agricultural Engineering, Texas A\&M University, College station, TX77840, USA \\ $6 \quad{ }^{2}$ Department of Rural and Bio-systems Engineering, Chonnam National University, Gwangju, Republic of Korea \\ $7 \quad$ Correspondence to: Rabi H. Mohtar (mohtar@tamu.edu)
}

\section{Abstract}

9 The aim of this study is to analyze the impacts of food trade on food security and water-land savings in the Arab World in

Keyword: Food security, Arab World, Virtual water trade; Degree centrality; Eigenvector centrality terms of virtual water trade (VWT). We estimated the total volume of virtual water imported for four major crops-barley, maize, rice, and wheat—from 2000 to 2012, and assessed their impacts on water and land savings, and food security. The largest volume of virtual water was imported by Egypt (19.9 billion m³/year), followed by Saudi Arabia (13.0 billion m³ year). Accordingly, Egypt would save 13.1 billion $\mathrm{m}^{3}$ in irrigation water and 2.1 million ha of crop area through importing crops. In addition, connectivity and influence of each country in the VWT network was analyzed using degree and eigenvector centralities. The study revealed that the Arab World focused more on increasing the volume of virtual water imported during the period 2006-2012 with little attention to the expansion of connections with country exporters, which is a vulnerable expansion. This study shed light on opportunities and risks associated with VWT and its role in food security and land management in the Arab World.

\section{Introduction}

Food trade is an important element of food security in water-scarce regions (Konar et al., 2012; Hanjra and Qureshi, 2010; Hoekstra, 2003) because food trade drives water conservation or loss in terms of the virtual water trade (VWT), which refers to the trade of water embedded in food products (Allan, 1993; Aldaya et al., 2010; Antonelli and Tamea, 2015). The concept and quantitative estimates of virtual water can help in realistically assessing water scarcity for each country, projecting future water demand for food supply, increasing public awareness about water, and identifying water-wasting processes in production (Oki and Kanae, 2004). For water-scarce countries, achieving water security through importing water intensive products could be a more attractive option, compared to producing all water-demanding products domestically (Hoekstra and Hung, 2005). The global volume of international crop-related virtual water flows averaged 695 billion $\mathrm{m}^{3} / \mathrm{year}_{\text {over the }}$ period 1995-1999, meaning that $13 \%$ of the water used for crop production in the world was not used for domestic consumption but rather for export in virtual form (Hoekstra and Hung, 2005). The International Water Management Institute (IWMI) and the Government Office for Science both state that the VWT could contribute to relieve water stress through using global water more efficiently, in the event of an increase in global food trade (Government Office for Science, London, 2011; Molden, 2007). In addition, Falkenmark and Lannerstad (2010) estimated that it would be necessary to double the VWT by 2050 to compensate for agricultural water deficits.

The VWT has been suggested as relevant to the water policy of a nation (Schyns and Hoekstra, 2014), providing a new point of view from which both food security and sustainable water management are considered (Novo et al., 2009). The VWT and the respective savings garnered through the trade of agricultural goods have been quantified in a number of studies. Oki and 
Kanae (2004) investigated whether VWT could save global water resources and determined that "real water" in exporting countries tends to be smaller than "virtual water" in importing countries. For example, approximately $1140 \mathrm{~km}^{3} / \mathrm{year}$ of virtual water was imported through the food trade, e,g., cereals, soybeans, and meat; however, $680 \mathrm{~km}^{3} /$ year of real water was used to produce those foods in exporting areas. This is due to the difference between crop water requirement between the importing and exporting country, with the later usually lower. Yang et al. (2006) revealed that the VWT could generate a global water saving because virtual water has flown primarily from countries of high crop water productivity to countries of low crop water productivity. In their study, globally, $336.8 \mathrm{~km}^{3} /$ year of virtual water was saved by the international trade of major food crops from 1997 to 2001, and 20.4\% of the total global net virtual water import was imported to countries that have water availability below $1700 \mathrm{~m}^{3}$ per capita, such as Arab countries. Fader et al. (2011) showed that the trade of crop products saves $263 \mathrm{~km}^{3} /$ year of virtual water, globally, representing $3.5 \%$ of the annual precipitation on cropland. In particular, water-scarce countries, such as China and Mexico, but also The Netherlands and Japan, saved large amounts of water by importing goods - from 25 to $73 \mathrm{~km}^{3}$ of water-because they would need relatively large amounts of water to produce the goods they import. According to the study by Biewald et al. (2014), blue water saving from international trade can bring enormous benefits in water-scarce regions; for example, 17 billion $\mathrm{m}^{3}$ of blue water per year were saved by the global food trade, and the value of blue water saving was estimated to 2.4 billion US\$.

Previous studies showed that the effective import of virtual water may reduce water use for domestic food production in importing countries and help alleviate water stress in water-scarce regions, such as the Arab World where the largest water deficit in the world exists (Gleick, 2000; World Bank, 2009). The critical condition of water scarcity in the Arab world will reach severe levels by 2025 (Tolba, 2009). In addition, if population increases rapidly and urbanization continues fast, availability of water could be reduced in Arab countries by about $50 \%$ by the year 2025 (Abahussain et al., 2002). Water shortages will certainly speed up the rate of desertification in the Arab countries with a larger deficit in freshwater (Abahussain et al., 2002). Agricultural water withdrawals account for over $85 \%$ of the total water withdrawn throughout the many countries of the Arab World (FAO, 2014). Irrigation systems in the Arab World are based on pumping groundwater resources such as aquifers, and water security is being threatened by declining aquifer levels and the extraction of nonrenewable groundwater (Antonelli and Tamea, 2015). In addition, Immerzeel et al. (2011) expected that the unfulfilled water demand in the entire Arab World would increase from the current level of 16\% to 51\% in 2040-2050 due to climate change. The IPCC projections also indicate that rainfall in the Arab region will become intense, and dry spells will become more pronounced. In addition, the zone of severely-reduced rainfall extends throughout the Mediterranean region and the northern Sahara (Hennessy et al., 2007). Milly et al. (2005) identify that climate change causes a drop in water run-off by $20 \%$ to $30 \%$ in most of Middle East North Africa (MENA) by 2050, mainly due to rising temperature s and lower precipitation. In addition, the regions including Syria, Lebanon, Israel, and Jordan will get drier, with significant rainfall decrease in the wet season.

Accordingly, food trade can be regarded as the most important factor for saving domestic water resources and decreasing water stress in addition to improving food security in the Arab World. This study addresses three questions that relate to the role and impact of the VWT in the Arab World, which are raised to draw attention to the complexity of the issue and the need for a broader view in assessment. These questions are: 1) What are the effects of the VWT on water savings and land tenure in the Arab World, 2) Has the structure of the virtual water import in the Arab World been vulnerable or robust? 3) Who are the influential importers and exporters in VWT network in the Arab World? The aim of this study is to analyze the quantitative and structural characteristics of VWT in the Arab World in order to understand the effects on water savings and land tenure from importing crops and identify the temporal changes of VWT structure.

First, we estimated the total volume of virtual water imported through four major crops — barley, maize, rice, and wheat —in the Arab World from 2000 to 2012, and the effects of importing crops on water and land savings were evaluated in each 
Hydrol. Earth Syst. Sci. Discuss., https://doi.org/10.5194/hess-2018-4

Arab country. However, food import can cause a decrease in local food production, which can be particularly a critical issue in the Arab World. Accordingly, we estimated water requirement of increasing $1 \%$ self-sufficiency of study crops in comparison to average self-sufficiency from 2000 to 2012 in terms of trade-off between water saving and food selfsufficiency.

Second, we analyzed the structural characteristics of the VWT in the Arab World using degree centrality, which represents the connectivity of a node in a network system, and categorized the countries in the Arab World in terms of vulnerable expansion (or reduction) and robust expansion (or reduction) in the VWT network. In addition, influence of each country was analyzed using eigenvector centrality to identify influential countries who could affect the entire VWT network in the Arab World. Understanding the VWT structure is important as quantifying the amount of import and export. Recent literature has emphasized the change in structure of the VWT in terms of a network approach (Dalin et al., 2012; Konar et al., 2012; Lee et al., 2016).

\section{Materials and Methods}

\subsection{Calculation of a virtual water trade using food trade and water footprint}

The VWT represents the water embedded in international trade, and the main factors for quantifying a VWT are trade data and water footprint (WFP, $\mathrm{m}^{3} / \mathrm{ton}$ ), which is the volume of water used for producing one ton of crops. Therefore, a VWT is calculated by multiplying the trade by its associated water footprint, as follows:

$$
V W T\left[n_{e}, n_{i}, \mathrm{c}, \mathrm{t}\right]=\mathrm{CT}\left[n_{e}, n_{i}, \mathrm{c}, \mathrm{t}\right] \times \operatorname{WFP}\left[n_{e}, c\right],
$$

in which variable VWT denotes the VWT from the exporting country, ne, to the importing country, ni, in year t, as a result of trade in crop c; CT represents the crop trade from the exporting country, ne, to the importing country, ni, in year $t$ as a result of trade in crop c; and WFP represents the water footprint of crop c in the exporting country, ne. The WFP of a crop is derived from the crop water requirement $\left(\mathrm{m}^{3} / \mathrm{ha}\right)$ per yield $(\mathrm{kg} / \mathrm{ha})$, as follows:

$W F P[c]=\frac{C W R[c]}{\text { Production }[c]}$,

where WFP ( $\left.\mathrm{m}^{3} / \mathrm{ton}\right)$ is water footprint of a crop c, CWR is the crop water requirement, and Production is the yield per year. The water footprint for a crop is divided into green and blue water footprints, based on the water resources (Hoekstra and Chapagain, 2008). Green water footprint indicates that water supplied by precipitation is retained in the soil of the root zone (Falkenmark, 1995), and blue water footprint is the water stored at the surface or in the ground. Therefore, green water footprint is related to rain-fed agriculture and blue water footprint is related to irrigation water provided by aquifers or surface bodies of water.

\subsection{Quantification of water and land savings by importing crops using water footprint and land productivity}

The import of crops could affect the water and land savings in the importing country. Therefore, the failure of trade could cause water and land shortages in the Arab World. Therefore, we analyzed water and lands requirements for producing as much crop as is imported in each Arab country. In other words, the water and land savings indicated resource requirements needed by the shift from crop import to domestic production. Although this assumption about water and land savings considers an extreme trade situation, these results could be used to understand how the international crop trade is important in the Arab World in terms of water and land savings. The national water and land savings indicated the amount of blue water and land requirements for substituting crops imported to domestic production. Thus, it was calculated as follows: Water saving ${ }_{c, i}=$ Import $_{c, i} \times$ Blue water footprint ${ }_{c, i}$

Lands saving $_{c, i}=$ Import $_{c, i} \times \frac{\text { Lands }_{c, i}}{\text { Production }_{c, i}}$ 
where $\mathrm{c}$ and $\mathrm{i}$ indicate crop and importer, and $\mathrm{w}$ indicates the water resource such as ground water, surface water, and treated water.

\subsection{Anal ysis of degree and eigenvector centrality in the virtual water trade network}

The VWT network indicates flows of virtual water among countries through crop trade, and thus, it consists of volume and links. In this study, we considered both volume and links of the VWT network for identifying changes in VWT structure, for example, vulnerable expansion (or reduction) and robust expansion (or reduction). Therefore, it is important to estimate the connectivity in a VWT network. Therefore, we applied the degree centrality, which is the number of edges incident on a given node (Freeman 1979). Degree centrality is divided into in- and out-degree centralities, depending on the direction, and the in-degree centrality of each Arab country was calculated because we focused more on the import of virtual water in the Arab World. An importer accompanying a high in-degree centrality has expanded connectivity with exporters, meaning that this importer could cope with an accidental disconnection from a certain exporter. A few studies that analyze the structure of the VWT using a network-based approach have been conducted (Konar et al., 2012; Dalin et al., 2012; Lee et al., 2016). The degree centrality of the VWT is:

$C_{i}=\sum_{j}^{N} V W T_{i j} /(N-1)$,

where $\mathrm{Ci}$ is the degree centrality of country $\mathrm{i}$ and $\mathrm{N}$ is the number of total countries. VWTij is the link between the ith and jth countries.

The entire network can be affected by a few nodes, which is influential nodes, and it is important to identify these nodes for understanding and estimating the change of entire network system. An eigenvector centrality can measure important and influence of each node in the entire network, and it is related not only of own connection but also connection of other node which connects to own. Therefore, a node is more influential if it is in relation with the nodes that are, themselves, influe ntial (Ruhnau, 2000). The eigenvector centrality assigns relative centrality to all of the nodes in the network, based on the principle that connections to high-level centrality nodes contribute more to the centrality of the nodes than equal connections to low-level centrality nodes (Ruhnau, 2000; Lee et al., 2016). Therefore, the eigenvector centrality of node is related to both the number of links to partners and their centrality (Ruhnau, 2000). Bonacich (1972) defined the centrality $c\left(v_{i}\right)$ of a node $v_{i}$ as the positive multiple of the sum of adjacent centralities, as follows:

$\lambda c\left(v_{i}\right)=\sum_{j=1}^{n} \alpha_{i j} c\left(v_{j}\right) \quad \forall i$.

In matrix notation, with $\mathrm{c}=\left(c\left(v_{i}\right), \ldots, c\left(v_{n}\right)\right)$, the above equation yields

$\mathrm{Ac}=\lambda \mathrm{c}$

Eigenvector centrality is determined by calculating the principal eigenvector that has the largest eigenvalue among every eigenvector. An eigenvector of the maximal eigenvalue with only non-negative entries does exist, and we call a non-negative eigenvector $(c \geq 0)$ of the maximal eigenvalue the principal eigenvector, and we call the entry $c\left(v_{i}\right)$ the eigenvectorcentrality of node $v_{i}$ (Ruhnau, 2000).

\subsection{Data collection and limitations of data availability}

A main data set was international trade, and the international trade data of the study crops from 2000 to 2012 was obtained from FAOSTAT (http://www.fao.org/faostat/), as shown in Table 1. The crop with the largest amount of import was wheat, with 359.7 million ton imported by the Arab World from 2000 to 2012, followed by maize (187.2 million ton), barley (116.4 million ton), and rice (49.0 million ton). Most of the Arab countries increased the imports of the four major crops from 2000 to 2012. In particular, the largest increase was represented in Egypt, for example, the amount of the imported crops in Egypt was 11.2 million ton in 2000 and it increased to 18.0 million ton in 2012.

To quantify VWT and assess its effect on water and land savings, water footprint data of crops was essential. However, water footprint of crops is based on crop water requirement and irrigation, thus various data are required for calculating it, 
Hydrol. Earth Syst. Sci. Discuss., https://doi.org/10.5194/hess-2018-4

160 for example climate data, crop information, irrigation scheduling, and soil characteristics. In addition, each variable is dependent on local characteristics, thus the study for national water footprint should be executed for each country, basin, or specific area, and it was out of the scope of this study. Therefore, the estimation of water footprint was not included but we applied water footprint data set from the study executed by Mekonnen and Hoekstra (2010). They estimated the average value of green and blue water footprints of crops and crop products at the national level from 1996 to 2005. In addition, the blue water footprint and land productivity for each country in the Arab World were applied to assess effects on water and land savings from importing crops. The blue water footprint for each country in the Arab World was also obtained from Mekonnen and Hoekstra (2010). Land productivity was calculated by the harvest area and crop production, which were collected from FAOSTAT (http://www.fao.org/faostat/), as shown in Table 2. Internal water resource and land area in each country were collected from World Bank (http://data.worldbank.org).

However, time scales of international trade were different from water footprint data. For example, water footprints used in this study were based on data from 1995 to 2005; however, we applied the food trade data from 2000 to 2012 . Therefore, the application of average water footprint to time-series trade data can cause a false estimate of the effects of VWT. However, the water footprint data indicated the representative index using average value, and the part of periods for water footprint is overlapped with the period of trade data. Therefore, even if there is limitation of data availability, the water footprint data from Mekonnen and Hoekstra (2010) can be used for estimating VWT in this study.

Table 1. The amount of crops imported by the Arab World from 2000 to 2012 (FAOSTAT).

Table 2. Cultivation area and production of four major crops in the Arab World.

\section{Results and Discussion}

\subsection{Quantification of virtual water trade in the Arab World from 2000 to 2012}

The total amount of green and blue water imported by each Arab country from 2000 to 2012 reached 921.2 and 80.5 billion $\mathrm{m}^{3}$, respectively, in the Arab World, is shown in Table 3 and Figure 1. The largest volume of green water was annually imported by Egypt (19.1 billion m³year), followed by Saudi Arabia (11.9 billion m³year). In addition, the largest amount of blue water was imported annually by Saudi Arabia ( 1.2 billion $\mathrm{m}^{3} / \mathrm{year}$ ), followed by the UAE ( 0.9 billion $\mathrm{m}^{3} / \mathrm{year}$ ). Over $70 \%$ of the green water imported into the Arab World annually through the barley trade (approximately 8.5 billion $\mathrm{m}^{3} /$ year) went to Saudi Arabia. The amount of virtual water imported through the trade of maize was 13.0 billion m³ear, with Egypt as the primary importer, importing $31 \%$ of the total imported into the Arab World. Rice is a blue-water-intensive crop, and the importers of rice also import a lot of water. About 3.0 billion $\mathrm{m}^{3} / \mathrm{year}$ of blue water were imported in the rice trade from 2000 to 2012, and Saudi Arabia, the UAE, and Iraq were the primary importers. The largest volume of virtual water imported by the Arab World was due to wheat trade. The annual amount of virtual water imported through wheat trade in the Arab World from 2000 to 2012 was approximately 42.6 billion $\mathrm{m}^{3} / \mathrm{year}$, but the amount of blue water was only $2.0 \mathrm{billion}^{3} / \mathrm{year}$. Over $35 \%$ of the virtual water imported through the wheat trade was imported by Egypt ( 15.7 billion $\mathrm{m}^{3} /$ year).

The volume of virtual water imports per capita (VWIcap) indicates how the countries are dependent on water resources from abroad. Figure 2 shows that the VWIcap was $1266.6 \mathrm{~m} / \mathrm{cap} /$ year in the UAE, which was the largest value in the Arab World. The UAE is strongly dependent on the import of virtual water, even though the UAE imports only 4.2 billion m³/year of virtual water. The VWIcap increased significantly in Saudi Arabia and Libya from 2000 to 2012. Saudi Arabia and Libya imported about 453.4 and $497.8 \mathrm{~m}$ /cap/year, respectively, of virtual water more in 2012 than in 2000 . Saudi Arabia was the second biggest importer in the Arab World, and its VWIcap was also the fifth highest in the Arab World. In the condition of increasing population, the VWIcap in the Arab World can be used to estimate the requirement of virtual water import in future, and it contribute to set water and food management for increasing domestic production and decreasing the VWIcap in the Arab World. 
201 We also focused on the volume of virtual water exported to the Arab World by each exporter from 2000 to 2012 (Figure 3). Through barley trade, Ukraine exported 41.1 billion $\mathrm{m}^{3}$ of green water to the Arab World, making up $27 \%$ of the total green water imported in the Arab World through barley. In terms of blue water traded through barley, five exporters (Germany, Australia, the Russian Federation, Ukraine, and India) provided $78 \%$ of the total blue water imported in the Arab World through barley. In the VWT via maize, Argentina contributed $40 \%$ of the total amount of green water imported by the Arab World through maize, but the blue water imported by the Arab World was primarily from the USA. In the VWT via rice, the major virtual water exporters to the Arab World were India, Thailand, and Pakistan. In particular, 30.4 billion $\mathrm{m}^{3}$ of blue water was imported from these countries from 2000 to 2012, which comprised 78\% of the blue water imported by the Arab World through rice. Wheat was the most representative crop imported by the Arab World. The Russian Federation and the USA provided 25\% (140.6 billion $\mathrm{m}^{3}$ ) and 21\% (111.2 billion $\mathrm{m}^{3}$ ), respectively, from 2000 to 2012, of the total amount of green water imported in the Arab World through wheat, and the remaining 55\% was divided among several exporters, including Australia, Canada, France, and Ukraine.

Table 3. The amount of virtual water imported by the Arab World from 2000 to 2012.

Figure 1. The total amount of virtual water imported by each country in the Arab World from 2000 to 2012, separated into green (upper) and blue (lower) water. The pie graph shows the annual import and proportion of each crop, and the size of the pie indicates the amount of annual virtual water imported from 2000 to 2012.

Figure 2. Virtual water imports per capita in 2000 and 2012.

Figure 3. The amounts of green water export (GWE) and blue water export (BWE) from the primary exporters to the Arab World from 2000 to 2012.

\subsection{Assessment of trade-offs between food self-sufficiency and water-lands savings through food trade in the Arab World}

Crop import could result in low food self-sufficiency in the Arab World, but water and land savings benefits of VWT. This study shows which countries were more successful in achieving water or land savings through importing crops. The national resource managers and trade policy makers in the Arab World would benefit from better understanding of the relationship between international trade and the preservation of national resources, and these results could provide useful information to each country in the Arab World.

Table 4 shows that water saving by crop import in Saudi Arabia was 8.14 billion m³year, 3.4 times larger than its internal water resources $\left(2.40\right.$ billion $\left.\mathrm{m}^{3}\right)$. However, the land saving was 1.5 million ha, making up $0.9 \%$ of the total agricultural lands in Saudi Arabia, which indicates that the crop trade in Saudi Arabia has more significant benefit in terms of water resource than land resource. Egypt and the UAE were also strongly influenced by the impact of crop import on water saving. On the other hand, Lebanon saved 0.06 billion $\mathrm{m}^{3}$ of water resources annually through cropimport, which was only $1.3 \%$ of its internal water resources. However, the crop import could bring a large amount of land saving; for example, about 0.24 million ha could be saved by crop import, comprising over $30 \%$ of the agricultural area in Lebanon. In addition, in Jordan and Kuwait, crop imports could have a strong impact on land saving.

However, increasing food imports is also correlated to decreasing domestic food production. Accordingly, it is important to understand the trade-off between water saving and food self-sufficiency in the Arab World. In this study, we defined selfsufficiency of crops as the ratio of imported crops to total consumption, and estimated the amount of blue water footprint for increasing self-sufficiency of crops by $1 \%$ in comparison to average self-sufficiency from 2000 to 2012, as shown in Table 5 . For example, the average self-sufficiency of wheat in Egypt from 2000 to 2012 was $47.64 \%$ and 278.77 million $^{3}$ irrigation water would be required to increase self-sufficiency by $1 \%$, in order to reach $48.64 \%$. The self-sufficiency of wheat in Saudi Arabia was $74.02 \%$ and 118.11 million $\mathrm{m}^{3}$ for increasing self-sufficiency by $1 \%$. In contrast, the self-sufficiency of wheat in Tunisia was $46.05 \%$ but the water requirement for increasing self-sufficiency by $1 \%$ was only 3.84 million $\mathrm{m}^{3}$. As shown in 
Hydrol. Earth Syst. Sci. Discuss., https://doi.org/10.5194/hess-2018-4

results, increase of food security accompanies a lot of water requirement in the Arab World and these results can give the useful information for analyzing trade-off between food and water securities in the Arab World in terms of sustainable development.

Table 4. The ratio of saved water and lands to internal water resources and agricultural land area in the Arab World

Table 5. Water requirement for increasing $1 \%$ self-sufficiency of study crops in comparison with average self-sufficiency in the Arab World from 2000 to 2012

\subsection{Analysis of structural changes in virtual water trade network centering the Arab World}

The VWT is regarded as significant element for sustainable water and food management in the Arab World where water is scarce. Accordingly, in this study we analysed the change of structural connectivity of VWT network in the Arab World using in-degree centrality from 2000 to 2012, and figured out the vulnerable expansion or reduction in VWT network, which consists of the volume and number of links. The in-degree centrality based on the number and volume of links in VWT network, which expressed to non-scaled in-degree centrality (NSInDC) which is based on the number of links, and scaled in-degree centrality (SInDC) which is based on the volume of links.

Figure 4 showed the NSInDC and SInDC in virtual water trade network by each country in the Arab World in 2012. Egypt and Yemen showed that NSCInD was lower but SInDC was higher than other countries, and it indicates the intensive connectivity with a few exporters. In contrast, Saudi Arabia had larger SInDC than other countries expect for Egypt and the NSCInD was also highest in the Arab World. Accordingly, Saudi Arabia has more distributed structure of VWT. In addition, UAE and Iraq had similar SInDC in 2012 but NSInDC was quite different; UAE (0.46) and Iraq (0.27). Furthermore, SInDC in Morocco (96.45) was larger than UAE (83.41) but NSInDC in Morocco (0.26) smaller than UAE (0.46). In comparison to UAE, Morocco had intensive connection with less exporters than UAE.

Figure 5 showed the temporal changes of NSInDC and the SInDC during two periods (2000-2006 and 2006-2012). In these results, the Arab World countries were divided into four types (I-IV). Type I countries show a robust expansion in the virtual water import, and the countries in this type increased the connectivity and volume of virtual water imported, simultaneously. Type II countries increased the volume of virtual water imported without expansion of connectivity. Type III and type IV countries show reductions in the virtual water import with and without reduction of connectivity, respectively. In the early 2000s, most of countries in Arab World tried to expand their trade structure by increasing both the connectivity to exporters and the volume of virtual water imported. In Bahrain, Omen, Qatar, Yemen, Saudi Arabia, Lebanon, and UAE NSInDC of the VWT network increased significantly from 2000 to 2006, which means that the trade connectivity expanded. The expanded structure of VWT indicates that the Arab countries is connected to various exporters and it can bring the security of import. In particular, import of food crops is essential factor in food security in the Arab World, even if they try to increase food se lfsufficiency through increasing domestic production. However. Egypt had the largest SInDC but NSInDC was located 6th in the Arab World. In 2006, Egypt expanded the connectivity in VWT network, as shown in increasing NSInDC, and Saudi Arabia also expanded the connectivity.

However, the VWT has become a more vulnerable structure in the Arab World in recent years. Most of the Arab countries increased the volume of virtual water imported, but the number of exporters that linked to the Arab countries decreased or increased little from 2006 to 2012. In particular, in 2012 most of countries kept the connectivity or reduced it except for Algeria, Iraq, Libya, and UAE. For example, virtual water imported in Lebanon significantly increased from 2006 to 2012 but NSInDC decreased in 2012. Figure 6 showed the change of virtual water import in Lebanon in 2000, 2006, and 2012. In 2000 Lebanon imported most of virtual water from the USA, Argentina, and Australia, thus VWT in Lebanon was strongly dependent on these exporters. However, Lebanon expended the VWT in 2006 and Russian federation, Turkey, and Kazakhstan contributed to virtual water import in Lebanon. Accordingly, the structure of VWT in Lebanon was getting to a distributed net work. However, the VWT in 2012 showed it was dominated by Ukraine and Russian federation even if Lebanon imported more 
virtual water in 2012 than 2006. Therefore, Lebanon should consider not only amount of virtual water but also structure of VWT for sustainable food security in the condition of strong dependency on crop import.

These results indicate that the dependence of the Arab World on virtual water import accelerated recently with the large increase in volume of virtual water imported. However, the connectivity of the VWT in the Arab World has not increased as much as the volume of virtual water imported increased.

Figure 4. In-degree centrality of each country in the Arab World in 2012

Figure 5. Country types in the Arab World according to the rate of increase in the in-degree centrality from 2000 to 2012

Figure 6. Virtual water import from exporters to Lebanon in 2000, 2006, and 2012

We also analyzed the influence of each country on entire VWT network centering the Arab World using eigenvector cent rality, as shown on Figure 7. In 2000, Egypt and Saudi Arabia were identified as the most influential importers in the Arab World and the USA and Australia were the most influential exporters. Accordingly, the entire VWT in the Arab World could be affected by these importers and exporters, and it means that the change of trade policy or food management in these countries could change the structure of VWT in the Arab World. In 2006 and 2012, the influential countries in the Arab World still were Egypt and Saudi Arabia but the influential exporters moved to Russian federation and Ukraine and Brazil. These results might contribute to understanding the key player in entire VWT centering the Arab World and other countries in the Arab World should observe the behavior of influential countries closely.

Figure 7. Eigenvector centrality of virtual water trade network in the Arab World at 2000,2006, and 2012

\subsection{The importance and limitations of concept of virtual water in the Arab World from a policy perspective}

Generally, the VWT is more related to resource management in exporting countries rather than importing countries because of the embedded water in food trade indicates water resource that is consumed for producing food products in the exporting country. However, VWT is also considered as an important issue in importing countries in terms of water and food security. For example, the reduction of VWT might be related to water consumption by replacing imported food products by domestic food products.

As mentioned above, the VWT can be a major resource in the Arab World. Accordingly, vulnerable VWT, for example low connectivity, can be a risk element for future food security risk management. In particular, the Arab World is strongly dependent on food products from exporting countries, and it implies a strong dependency on water resource from exporting countries. Therefore, water shortages or low food production in exporting countries might cause increasing food price in the Arab World but also increasing domestic water use for increasing domestic food production.

In this study, we believe that the VWT in the Arab World can be the key factor for bridging water and food, and it is important to quantify the influence of trade on water and food management. In addition, this study revealed vulnerability (or robust) expansion (or reduction) and influential trader in VWT network in the Arab World through in-degree and eigenvector centrality indices. If a country in the Arab World has low connectivity but a large amount of virtual water import, this country should revaluate their vulnerable trade structure and change the trade policy or water-food management.

However, the application of the concept of VWT is under critical discussion(Wichelns, 2010). First, water footprints bring new concepts of water management, but it is also difficult to link to operating water resource systems. Water footprint is more related to water consumption rather than water supply. We can quantify water requirement for producing food products or water saving by importing them using water footprint and VWT. However, the operation of water facilities, for example reservoir, desalination plant, and ground water pumping station, are affected by monthly rainfall and ground water level, development of technology, fertilizer usage, irrigation scheduling and system. Therefore, we need to realize that water footprint can be changed by various factors. Second, VWT could contribute to connecting water management to food security; however, food trade is affected by the scarcity or affluence of other important resource such as capital, labor, and land (Biewald et al., 
2014). In particular, economic values such as price of food products is the main driver in global food trade but there is no global value established for virtual water. Therefore, it is difficult to apply virtual water to trade policy in terms of eco nomic efficiency. Therefore, policy makers or resource manager in the Arab World should consider not only the effects of VWT but also the difficulty in adapting virtual water to policies for resource management.

Despite these limitations, this study attempted to analyze the VWT through various perspectives. Through the in-degree centrality of the VWT network, we identified that most countries in the Arab World increased connections with exporters and the volume of virtual water imported between 2000 and 2006. However, most countries increased the volume of virtual water imported without increasing the expansion of connections between 2006 and 2012. These results could underscore the fact that the VWT structure has not recently increased in robustness. We believe that virtual water has a role in achieving sustainable water, land, and food security, even if there are limitations and difficulties in applying the virtual water concept.

\section{Conclusions}

The VWT, importing water in virtual form, could be a major water portfolio that dominates water management in the waterscarce countries of the Arab World. Since the virtual water concept was introduced, various studies have been conducted to quantify the volume of the VWT. In water-deficit areas such as the Arab World, the VWT can offer new perspectives for understanding and solving water stress and scarcity. The amount of virtual water imported is regarded as the most important factor in determining water and food security, and the results of water and land savings by crop import in the Arab World could show the importance of international trade.

In summary, policy makers can benefit by considering both the quantitative impacts of VWT and the structural change of VWT such as vulnerable expansion (or reduction) in the Arab World. The intensity and connectivity of VWT, which were analysed in this study, can be major component for integrating food and water policy in the Arab World, and this study might give important information to policy maker for evaluating future scenarios about resource management toward sustainability in the Arab World.

\section{Acknowledgment}

We appreciate the use of the national water footprint data from Mekonnen and Hoekstra (2010). The international trade data, crop production, and harvested arear from 2000 to 2012 are available from the FAOSTAT.

\section{References}

Abahussain, A.A., Abdu, A.S., Al-Zubari, W.K., El-Deen, N.A., and Abdul-Raheem, M.: Desertification in the Arab Region: analysis of current status and trends. Journal of Arid Environments, 51(4), 521-545, 2002.

Aldaya, M.M., Allan, J.A., and Hoekstra, A.Y.: Strategic importance of green water in international crop trade. Ecological Economics, 69, 887-894., 2010.

Allan, J.: Fortunately there are substitutes for water otherwise our hydro-political futures would be impossible In: Priorities for water resources allocation and management, ODA, London 13-26, 1993.

Antonelli, M., Laio, F., and Tamea, S.: Food security and VWT in the Middle East and North Africa. International Journal of Water Resources Development, 31(3), 326-342, 2015.

Biewald, A., Rolinski, S., Camoen, H.L., Schmitz, C., and Dietrich, J.P.: Valuing the impact of trade on local blue water. Ecological Economics, 101, 43-53, 2014. 
Hydrol. Earth Syst. Sci. Discuss., https://doi.org/10.5194/hess-2018-4

Manuscript under review for journal Hydrol. Earth Syst. Sci.

Discussion started: 17 January 2018

(c) Author(s) 2018. CC BY 4.0 License.
Hydrology and

Earth System

Sciences

Discussions

364 Dalin, C., Konar, M., Hanasaki, N., Rinaldo, A., and Rodriguez-Iturbe, I.: Evolution of the global VWT network. Proc. Natl.

Acad. Sci. U.S.A., 109(16), 5989-5994, 2012.

Fader, M., Gerten, G., Thammer, M., Heinke, J., Lotze-Campen, H., Lucht, W., and Cramer, W.: Internal and external greenblue agricultural water footprints of nations, and related water and land savings through trade. Hydrology and Earth System Sciences, 15, 1641-1660, 2011.

Falkenmark, M.: Land-water linkages: a synopsis. Land and Water integration and river basin management. FAO Land and Water Bulletin, 1, 15-16, 1995.

Falkenmark, M., and Lannerstad, M.: Food security in water-short countries- Coping with carrying capacity overshoot. Fourth Botin Foundation Water Workshop, 2010.

Food and Agriculture Organization of the United Nations (FAO).: on-line database. Retrieved from http://www.fao.org/nr/water/aquastat/main/index.stm, 2014.

Freeman, L.C.: Centrality in social network: conceptual clarification. Social Networks, 1, 215-239, 1979.

Gleick, P. H.: The world's water 2000-2001. The biennial report on freshwater resources, 19-38, 2000. Government Office for Science, London.: Foresight. The Future of Food and Farming, 2011.

Hanjra, M., and Qureshi, M.: Global water crisis and future food security in an era of climate change, Food Policy, 35, 365$377,2010$.

Hennessy, K. B., Fitzharris, B., Bates, B. C., Harvey, N., Howden, M., Hughes, L., ... and Warrick, R.: Australia and New Zealand: climate change 2007: impacts, adaptation and vulnerability: contribution of Working Group II to the Fourth Assessment Report of the Intergovernmental Panel on Climate Change, 2007.

Hoekstra, A.Y.: VWT: Proceedings of the international expert meeting on VWT. Value of Water Research Series No.12, UNESCO-IHE: Delft, the Netherland, 2003.

Hoekstra, A.Y., and Chapagain, A.K.: Globalisation of Water: Sharing the Planet's Freshwater Resources. Blackwell Publishing, 2008.

Hoekstra, A.Y., and Hung, P.Q.: Globalisation of water resources: international virtual water flows in relation to crop trade. Global Environment Change, 15, 45-56, 2005.

Immerzeel, W., Droogers, P., Terink, W., Hoogeveen, J., Hellegers, P., Bierkens, M., and van Beek, R.: Middle-East and Northern Africa water outlook. World Bank Study. Future Water Report, 98, 2011.

Konar, M., Dalin, C., Hanasaki, N., Rinaldo, A., and Rodriguez-Iturbe, I.: Temporal dynamics of blue and green VWT networks. Water Resources Research, 48(7), 2012.

Lee, S.H., Mohtar, R.H., Choi, J.Y., and Yoo, S.H.: Analysis of the characteristics of the global VWT network using degree and eigenvector centrality, with a focus on food and feed crops. Hydrology and Earth System Sciences, 20(10), 4223, 2016. Mekonnen, M.M., and Hoekstra, A.Y.: The green, blue and grey water footprint of crops and derived crop products. Value of Water Research Series No.47, UNESCO-IHE: Delft, the Netherland., 2010.

Milly, P. C., Dunne, K. A., and Vecchia, A. V.: Global pattern of trends in streamflow and water availability in a changing climate. Nature, 438(7066), 347-350, 2005.

Molden, D.: Water for food, water for life: a comprehensive assessment of water management in agriculture: summary. IWMI Books, Reports H039769 International Water Management Institute, 2007.

Novo, P., Garrido, A., and Varela-Ortega, C.: Are virtual water "flows" in Spanish grain trade consistent with relative water scarcity?. Ecological Economics, 68, 1454-1464, 2009.

Oki, T., and Kanae, S.: VWT and water resource. Water Science \& Technology, 49(7), 203-209, 2004.

Schyns, J.F., and Hoekstra, A.Y.: The Added Value of Water Footprint Assessment for National Water Policy: A Case Study for Morocco. Plos ONE, 9(6), e99705, 2014. 
Hydrol. Earth Syst. Sci. Discuss., https://doi.org/10.5194/hess-2018-4

Manuscript under review for journal Hydrol. Earth Syst. Sci.

Discussion started: 17 January 2018

(c) Author(s) 2018. CC BY 4.0 License.

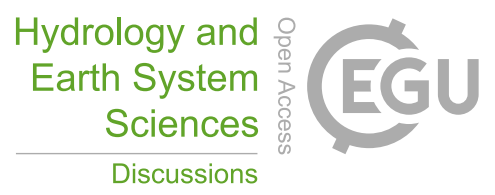

(c) (i)

406 Tolba, M. K., and Saab, N. W.: Arab environment: Climate change. In Beirut, Arab Forum for Environment and

407 Development, 2009.

408 Wichelns, D.: Virtual water: A helpful perspective, but not a sufficient policy criterion. Water Resources

409 Management, 24(10), 2203-2219, 2010.

410 World Bank.: Water in the Arab World: Management Perspectives and Innovations, edited by N. Vijay Jagannathan, Ahmed

411 Shawky Mohamed, Alexander Kremer. Washington DC: World Bank, 2009.

412 Yang, H., Wang, L., Abbaspour, K.C., and Zehnder, A.J.B.: VWT: an assessment of water use efficiency in the international

413 food trade. Hydrology and Earth System Sciences, 10, 443-454, 2006.

414 
Hydrol. Earth Syst. Sci. Discuss., https://doi.org/10.5194/hess-2018-4

Manuscript under review for journal Hydrol. Earth Syst. Sci.

Discussion started: 17 January 2018

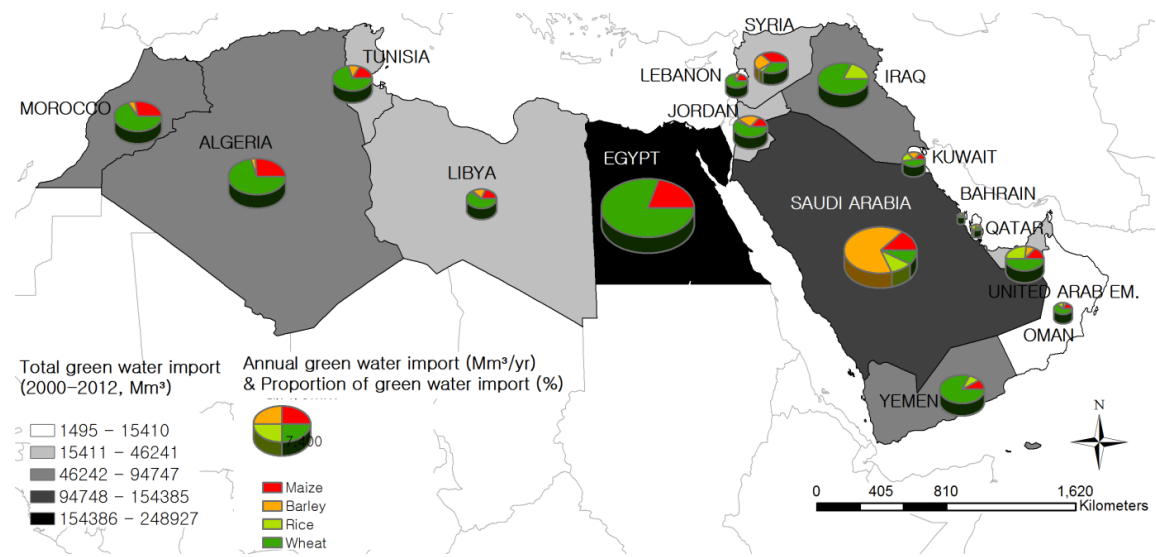

(a) Green water imports

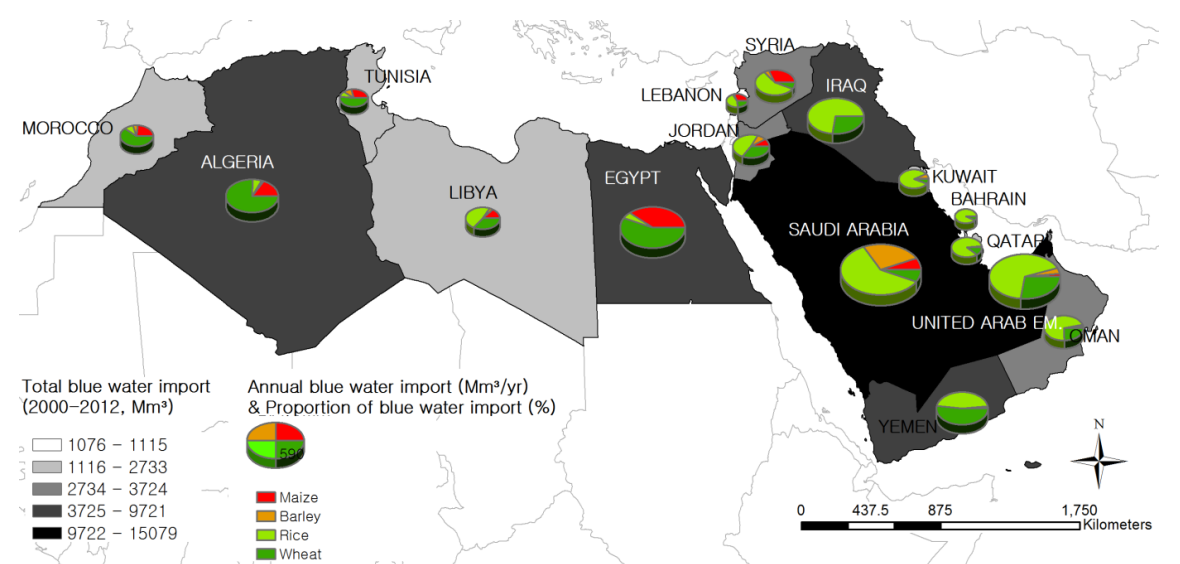

(b) Blue water imports

Figure 1. The total amount of virtual water imported by each country in the Arab World from 2000 to 2012, separated into green (upper) and blue (lower) water. The pie graph shows the annual import and proportion of each crop, and the size of the pie indicates the amount of annual virtual water imported from 2000 to 2012. 
Hydrol. Earth Syst. Sci. Discuss., https://doi.org/10.5194/hess-2018-4

Manuscript under review for journal Hydrol. Earth Syst. Sci.

Discussion started: 17 January 2018

(c) Author(s) 2018. CC BY 4.0 License.
Hydrology and

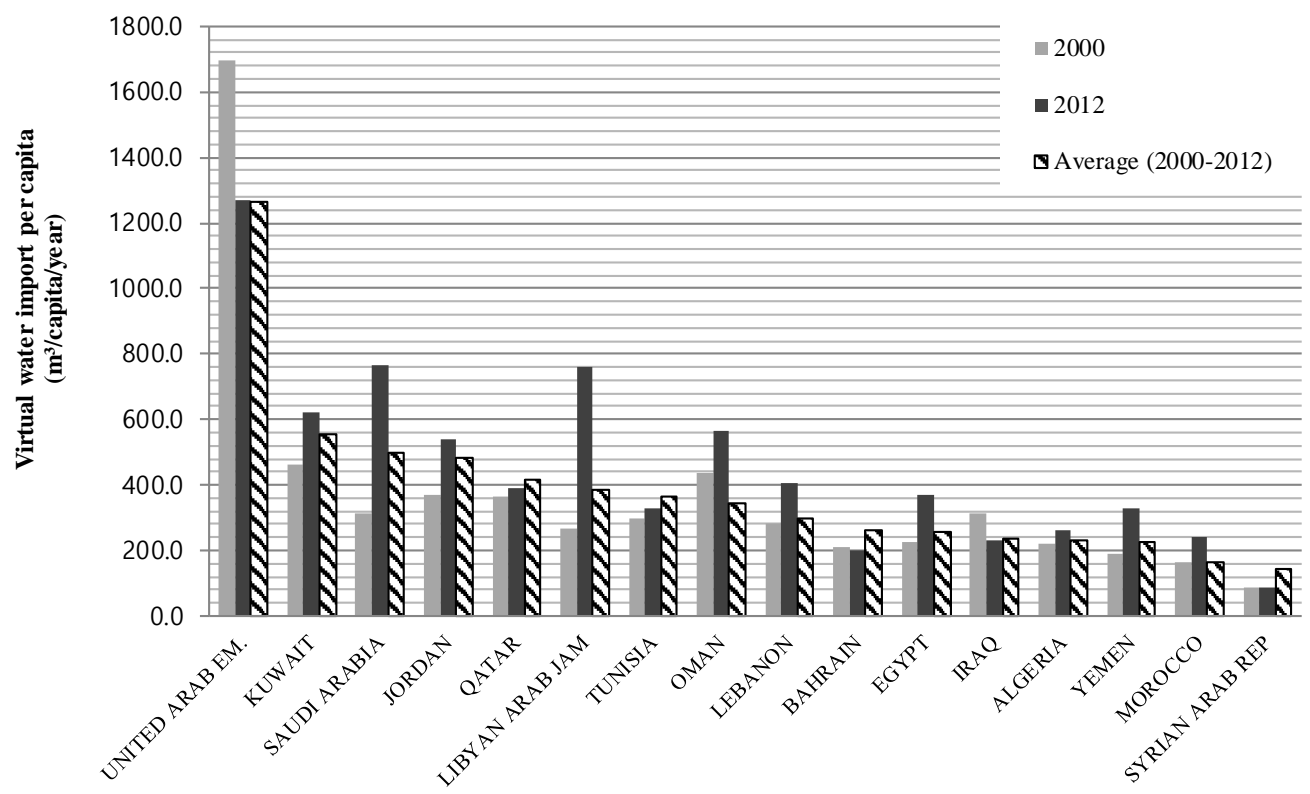

425

426

427

Figure 2. Virtual water import per capita in 2000 and 2012. 
Hydrol. Earth Syst. Sci. Discuss., https://doi.org/10.5194/hess-2018-4

Manuscript under review for journal Hydrol. Earth Syst. Sci.

Discussion started: 17 January 2018

(c) Author(s) 2018. CC BY 4.0 License.
Hydrology and

Earth System

Sciences

Discussions

(c) (i)
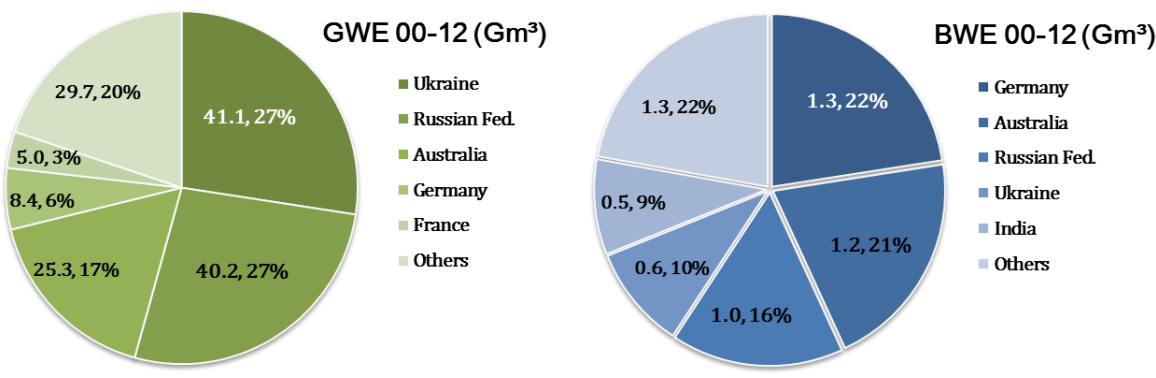

(a) Barley

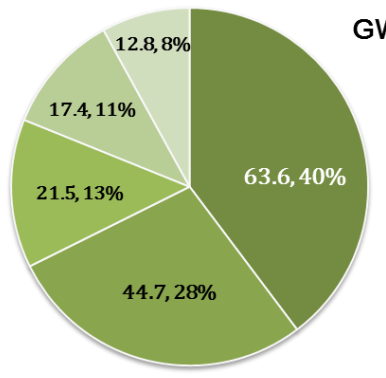

GWE 00-12 $\left(\mathrm{Gm}^{3}\right)$

- Argentina

- USA

Brazil

Ukraine

Ohters

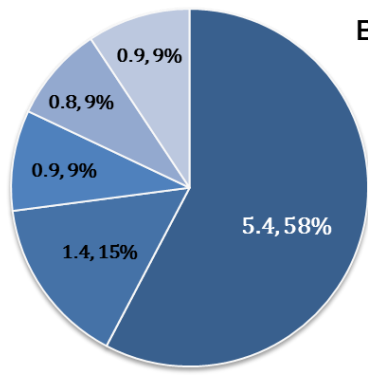

BWE 00-12 $\left(\mathrm{Gm}^{3}\right)$

- USA

- Ukraine

- Argentina

- Russian Fed

Ohters

(b) Maize
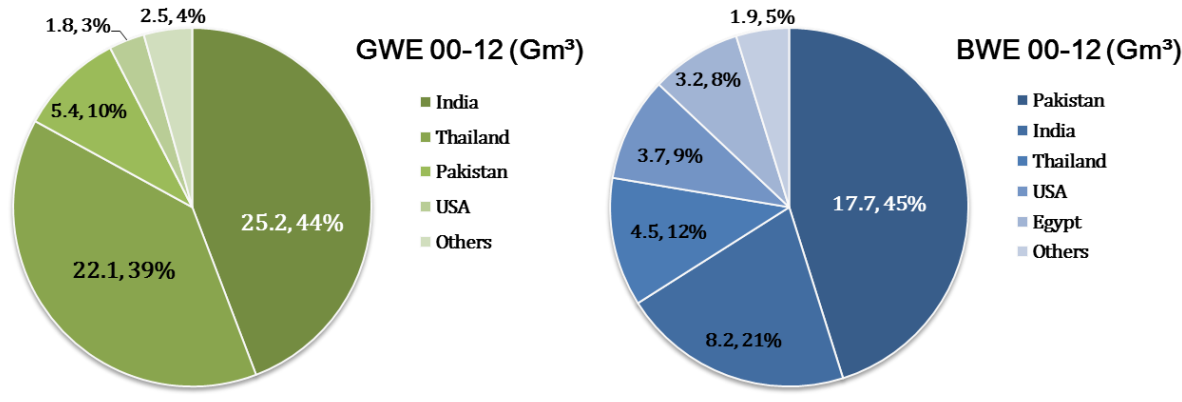

(c) Rice
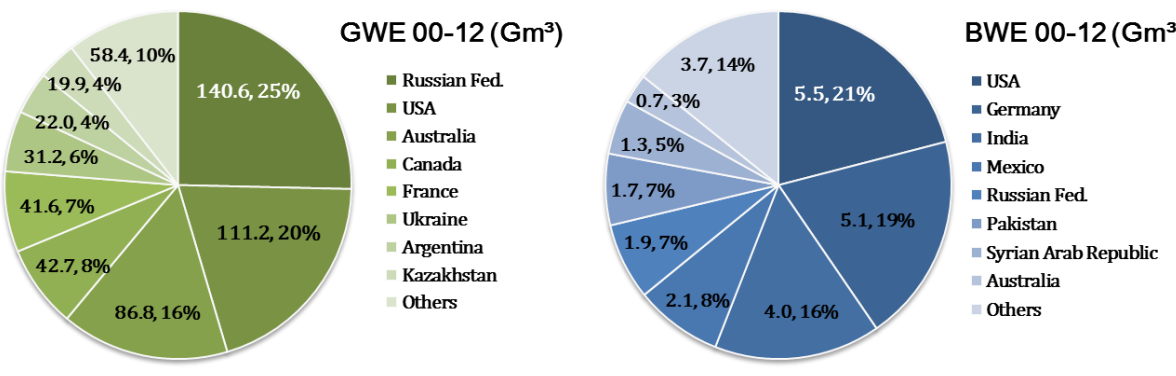

(d) Wheat

Figure 3. The amounts of green water export (GWE) and blue water export (BWE) from the primary exporters to the Arab World from 2000 to 2012 
Hydrol. Earth Syst. Sci. Discuss., https://doi.org/10.5194/hess-2018-4

Manuscript under review for journal Hydrol. Earth Syst. Sci.

Discussion started: 17 January 2018

(c) Author(s) 2018. CC BY 4.0 License.

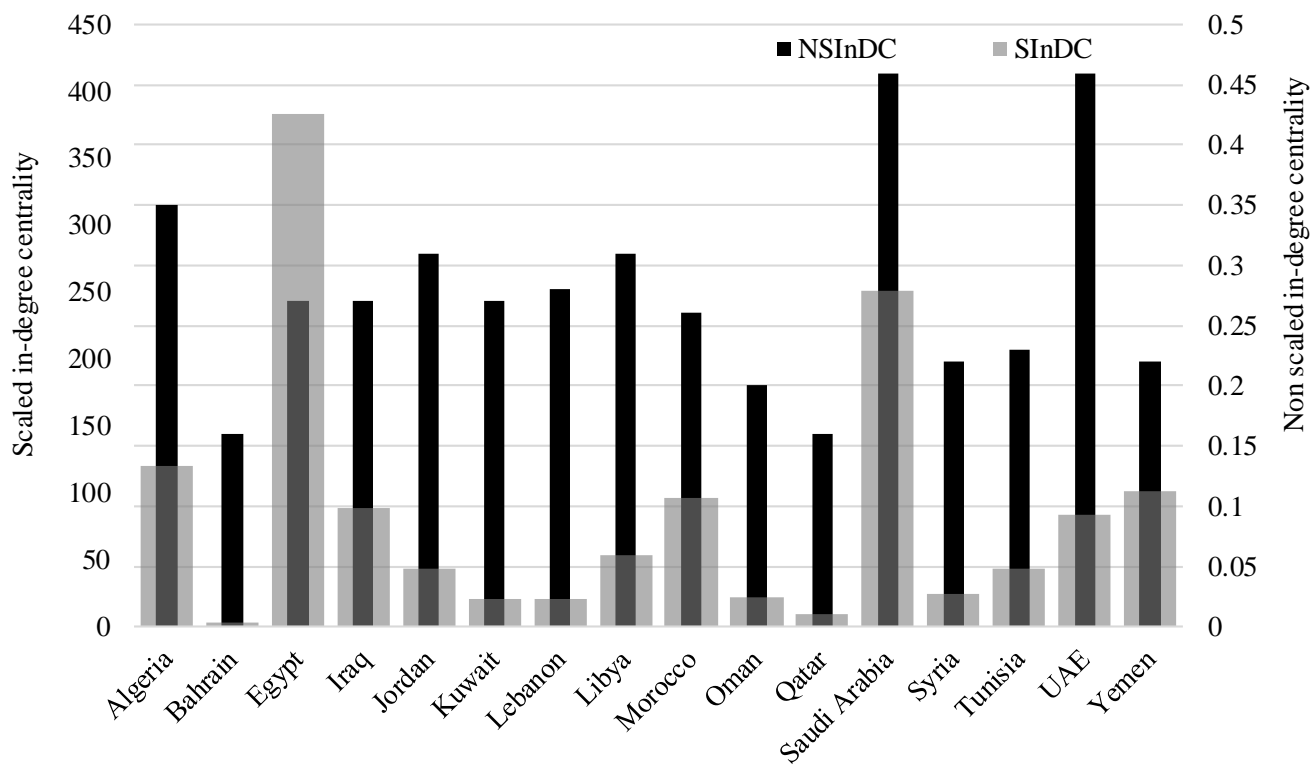

Figure 4. In-degree centrality of each country in the Arab World in 2012

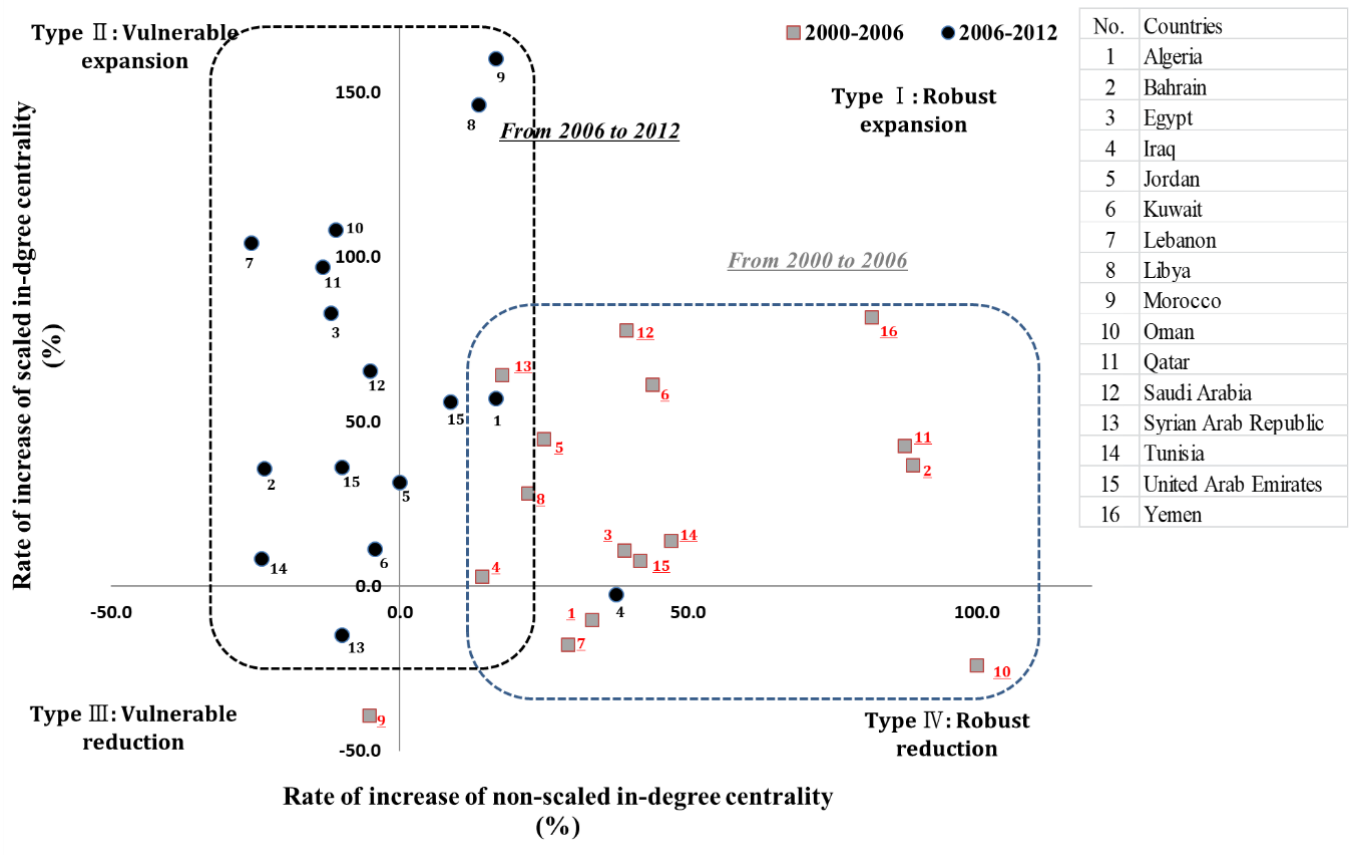

Figure 5. Country types in the Arab World according to the rate of increase in the in-degree centrality from 2000 to 2012 
Hydrol. Earth Syst. Sci. Discuss., https://doi.org/10.5194/hess-2018-4

Manuscript under review for journal Hydrol. Earth Syst. Sci.

Discussion started: 17 January 2018

(c) Author(s) 2018. CC BY 4.0 License.
Hydrology and Earth System Sciences Discussions

\section{(c) (1)}

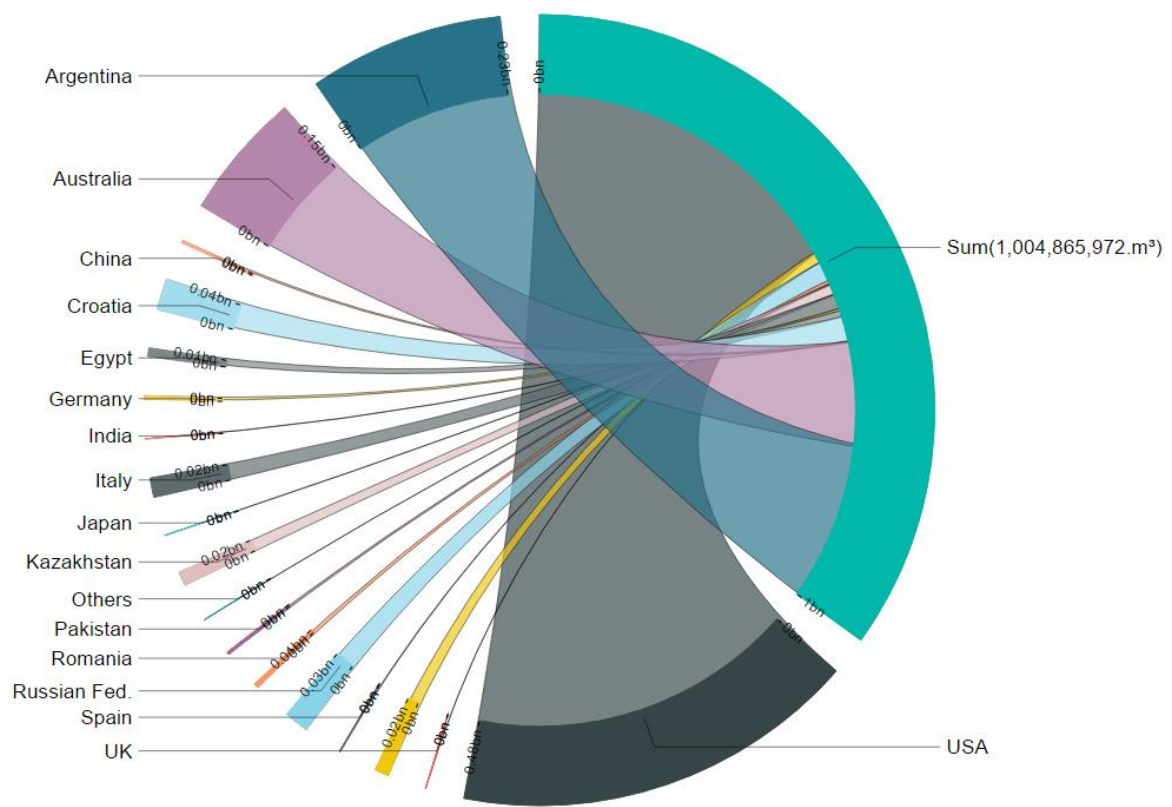

(a) 2000

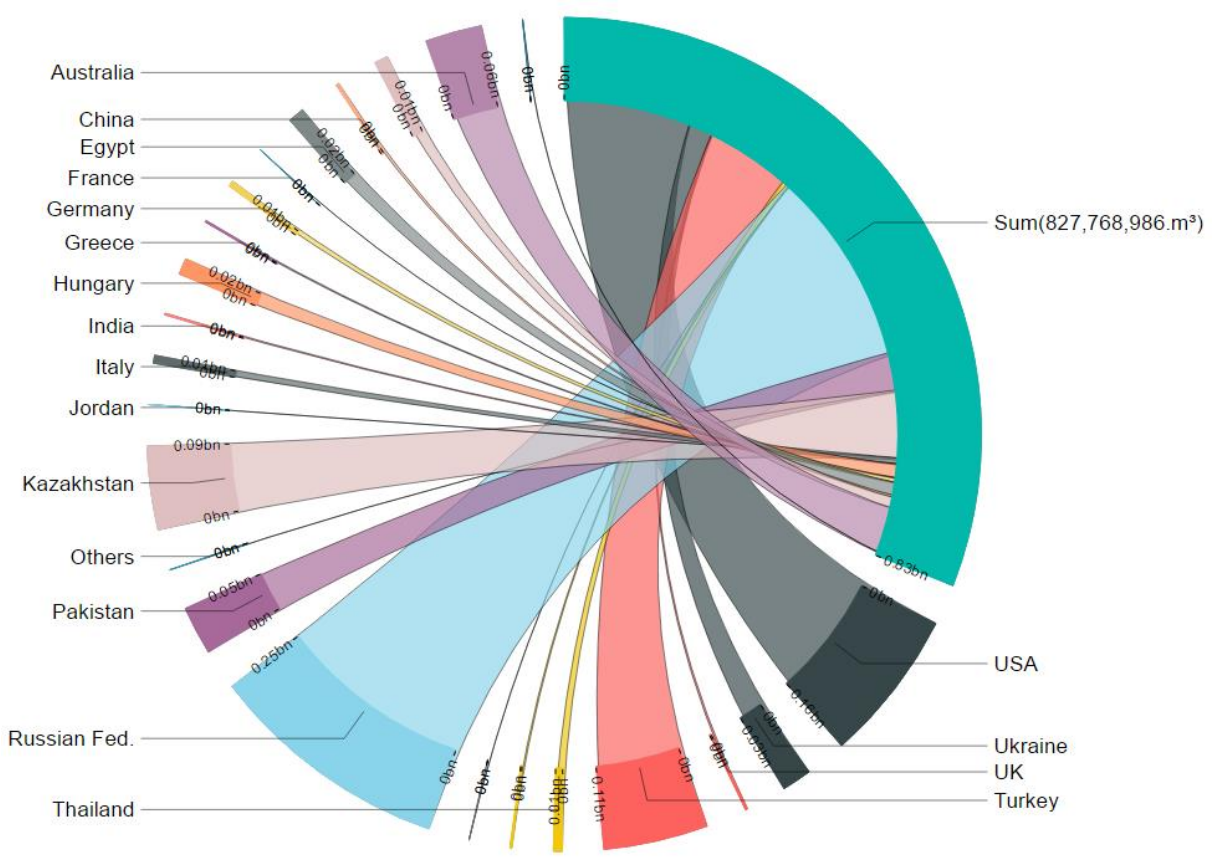

(b) 2006 
Hydrol. Earth Syst. Sci. Discuss., https://doi.org/10.5194/hess-2018-4

Manuscript under review for journal Hydrol. Earth Syst. Sci.

Discussion started: 17 January 2018

(c) Author(s) 2018. CC BY 4.0 License.
Hydrology and Earth System Sciences

Discussions

(c) (i)

454

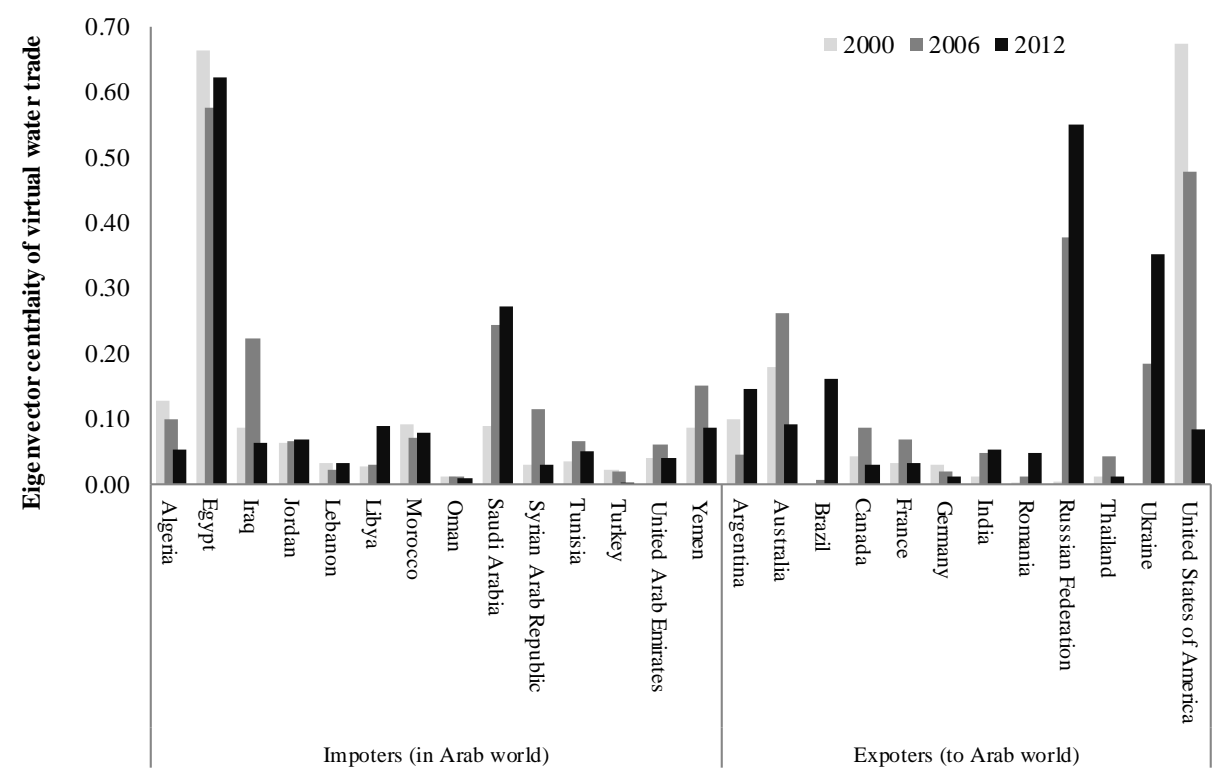

(c) 2012

Figure 6. Virtual water import from exporters to Lebanon in 2000, 2006, and 2012

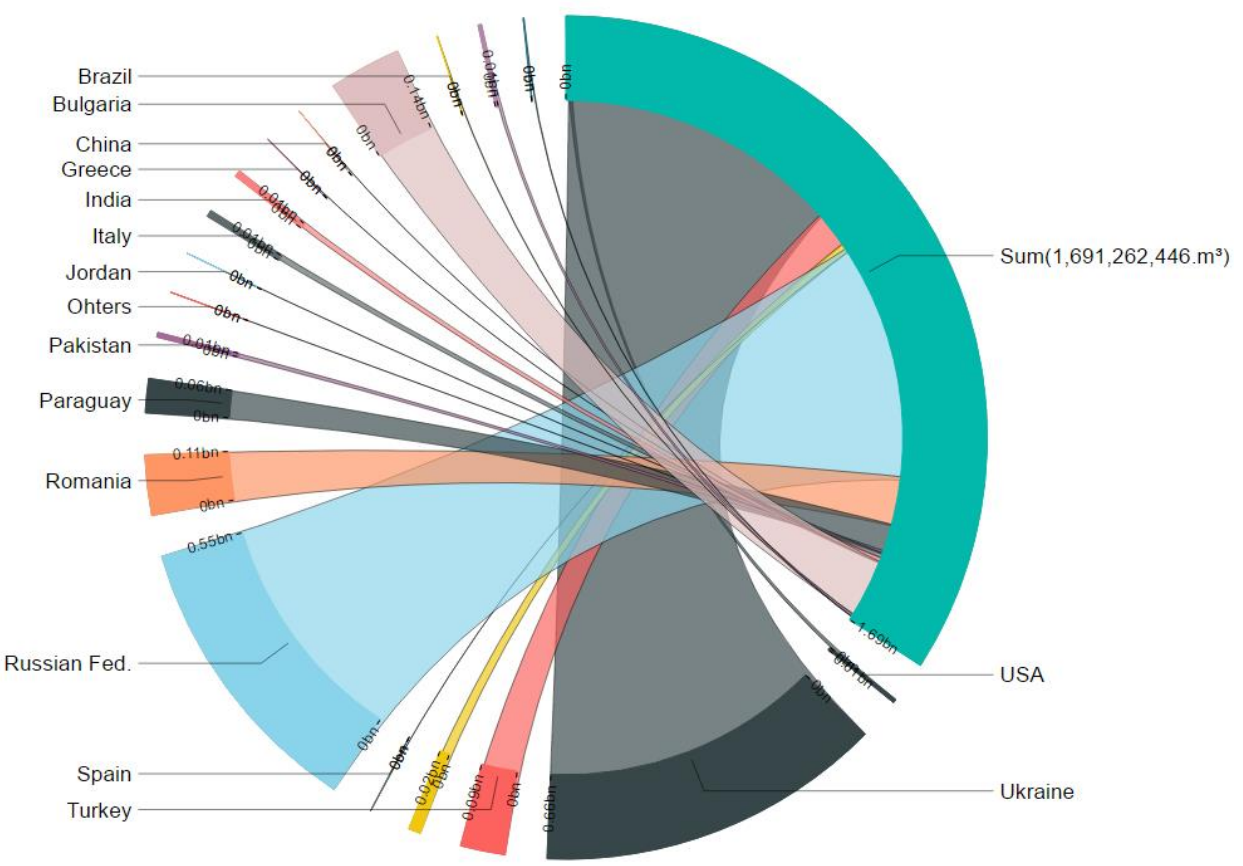

Figure 7. Eigenvector centrality of virtual water trade network in the Arab World at 2000, 2006, and 2012 
Hydrol. Earth Syst. Sci. Discuss., https://doi.org/10.5194/hess-2018-4

Manuscript under review for journal Hydrol. Earth Syst. Sci.

Discussion started: 17 January 2018

(c) Author(s) 2018. CC BY 4.0 License.

Discussions

\section{(c) (i)}

Table 1. The amount of crops imported by the Arab World from 2000 to 2012

\begin{tabular}{ccccc|cccc}
\hline \multirow{2}{*}{$\begin{array}{c}\text { Importers } \\
\text { in the Arab World }\end{array}$} & \multicolumn{6}{c}{ Total import } \\
\cline { 2 - 9 } & \multicolumn{7}{c}{ Crop import from 2000 to 2012 } \\
\cline { 2 - 9 } & Barley & Maize & Wheat & Rice & Barley & Maize & Wheat & Rice \\
\hline ALGERIA & 3.04 & 27.46 & 69.73 & 0.61 & 234 & 2,113 & 5,364 & 47 \\
BAHRAIN & 0.00 & 0.09 & 0.52 & 0.62 & 0 & 7 & 40 & 48 \\
EGYPT & 0.32 & 65.96 & 107.85 & 0.60 & 25 & 5,074 & 8,296 & 46 \\
IRAQ & 0.25 & 0.23 & 33.10 & 9.65 & 35 & 19 & 2,546 & 742 \\
JORDAN & 6.34 & 5.02 & 10.30 & 1.79 & 488 & 386 & 793 & 137 \\
KUWAIT & 2.32 & 1.75 & 3.70 & 2.23 & 178 & 134 & 285 & 171 \\
LEBANON & 0.64 & 3.77 & 4.78 & 0.60 & 49 & 290 & 367 & 46 \\
LIBYA & 2.94 & 5.58 & 10.45 & 1.59 & 226 & 429 & 804 & 123 \\
MOROCCO & 5.10 & 18.81 & 38.93 & 0.17 & 393 & 1,447 & 2,994 & 13 \\
OMAN & 0.47 & 1.29 & 3.75 & 1.54 & 36 & 100 & 288 & 119 \\
QATAR & 0.43 & 0.05 & 0.62 & 1.14 & 33 & 4 & 48 & 87 \\
SAUDI ARABIA & 81.29 & 20.80 & 9.11 & 13.12 & 6,253 & 1,600 & 701 & 1,009 \\
SYRIA & 5.11 & 17.15 & 5.91 & 2.62 & 393 & 1,319 & 455 & 202 \\
TUNISIA & 5.30 & 9.59 & 19.84 & 0.23 & 407 & 738 & 1,526 & 17 \\
UAE & 2.80 & 5.20 & 13.83 & 8.88 & 215 & 400 & 1,064 & 683 \\
YEMEN & 0.02 & 4.47 & 27.26 & 3.63 & 3 & 344 & 2,097 & 279 \\
\hline Total & 116.4 & 187.2 & 359.7 & 49.0 & 8,968 & 14,404 & 27,668 & 3,769 \\
\hline
\end{tabular}


Hydrol. Earth Syst. Sci. Discuss., https://doi.org/10.5194/hess-2018-4

Manuscript under review for journal Hydrol. Earth Syst. Sci.

Discussion started: 17 January 2018

(c) Author(s) 2018. CC BY 4.0 License.

461 Table 2 Cultivation area and production of four major crops in the Arab World.

\begin{tabular}{ccccc}
\hline Importers & \multicolumn{3}{c}{ Average cultivation area from 2000 to 2012 (ha/year) } \\
in the Arab World & Barley & Maize & Wheat & Rice \\
\hline ALGERIA & 760,545 & 308 & $1,658,197$ & - \\
EGYPT & 68,103 & 876,153 & $1,180,644$ & 625,626 \\
IRAQ & 914,074 & 128,842 & $1,451,219$ & 85,182 \\
JORDAN & 31,158 & 947 & 20,116 & - \\
KUWAIT & 1,058 & 290 & 173 & - \\
LEBANON & 13,515 & 949 & 45,380 & - \\
LIBYA & 191,641 & 1,356 & 165,469 & - \\
MOROCCO & $2,118,032$ & 226903 & $2,910,977$ & 5,876 \\
OMAN & 1,002 & - & 426 & - \\
QATAR & 947 & 94 & 15 & - \\
SAUDI ARABIA & 12,279 & 16,689 & 374,414 & - \\
SYRIA & $1,313,101$ & 53,405 & $1,667,229$ & - \\
TUNISIA & 385,189 & - & 722,038 & - \\
UAE & 14 & 144 & 18 & - \\
YEMEN & 39,276 & 40,774 & 110,138 & - \\
Importers & & Average production from 2000 to 2012 (ton/year) & \\
in the Arab World & Barley & Maize & Wheat & Rice \\
\hline ALGERIA & $1,049,710$ & 1,128 & $2,313,464$ & - \\
EGYPT & 134,034 & $6,812,845$ & $7,549,253$ & $6,023,684$ \\
IRAQ & 751,099 & 307,682 & $2,009,972$ & 232,040 \\
JORDAN & 22,757 & 17,514 & 23,379 & - \\
KUWAIT & 2,191 & 5,855 & 345 & - \\
LEBANON & 24,834 & 3,579 & 126,623 & - \\
LIBYA & 94,107 & 2,997 & 128,149 & - \\
MOROCCO & $1,867,670$ & 159,127 & $4,200,596$ & 36,936 \\
OMAN & 3,027 & - & 1,432 & - \\
QATAR & 2,841 & 1,329 & 34 & - \\
SAUDI ARABIA & 68,366 & 86,181 & $1,997,598$ & - \\
SYRIA & 817,609 & 211,675 & $4,008,420$ & - \\
TUNISIA & 411,431 & - & $1,302,438$ & - \\
UAE & 111 & 2,931 & 74 & - \\
YEMEN & 32,248 & 57,329 & 173,437 & - \\
\hline
\end{tabular}


Hydrol. Earth Syst. Sci. Discuss., https://doi.org/10.5194/hess-2018-4

Manuscript under review for journal Hydrol. Earth Syst. Sci.

Discussion started: 17 January 2018

Table 3 The amount of virtual water imported by the Arab World from 2000 to 2012.

\begin{tabular}{|c|c|c|c|c|c|c|c|c|}
\hline \multirow{2}{*}{$\begin{array}{l}\text { Importers } \\
\text { in the Arab World }\end{array}$} & \multicolumn{4}{|c|}{$\begin{array}{c}\text { Green water import } \\
\left(10^{6} \mathrm{~m}^{3} / \text { year }\right)\end{array}$} & \multicolumn{4}{|c|}{$\begin{array}{c}\text { Blue water import } \\
\left(10^{6} \mathrm{~m}^{3} / \text { year }\right)\end{array}$} \\
\hline & Barley & Maize & Wheat & Rice & Barley & Maize & Wheat & Rice \\
\hline ALGERIA & 242.0 & $1,883.6$ & $5,104.8$ & 57.8 & 7.8 & 76.6 & 371.1 & 33.5 \\
\hline BAHRAIN & 0.4 & 7.5 & 62.7 & 44.4 & 0.2 & 0.3 & 7.1 & 78.2 \\
\hline EGYPT & 37.3 & $3,798.4$ & $15,254.1$ & 58.4 & 1.1 & 295.6 & 418.6 & 32.5 \\
\hline IRAQ & 33.2 & 16.7 & $4,645.8$ & $1,027.8$ & 2.2 & 1.3 & 153.9 & 404.8 \\
\hline JORDAN & 656.8 & 364.2 & $1,483.9$ & 81.2 & 20.8 & 20.8 & 84.5 & 115.0 \\
\hline KUWAIT & 257.0 & 159.1 & 557.7 & 211.6 & 9.7 & 2.3 & 10.2 & 138.1 \\
\hline LEBANON & 84.7 & 211.0 & 749.5 & 30.0 & 2.3 & 25.6 & 18.9 & 36.0 \\
\hline LIBYA & 359.6 & 408.9 & $1,245.4$ & 56.0 & 8.4 & 26.8 & 75.3 & 99.7 \\
\hline MOROCCO & 318.6 & $1,383.2$ & $3,345.0$ & 8.9 & 12.1 & 46.1 & 118.8 & 20.4 \\
\hline OMAN & 52.7 & 123.2 & 470.8 & 107.6 & 5.4 & 4.1 & 67.8 & 201.3 \\
\hline QATAR & 50.9 & 6.4 & 76.4 & 77.6 & 2.4 & 0.3 & 19.1 & 146.9 \\
\hline SAUDI ARABIA & $8,154.5$ & $1,521.4$ & 974.0 & $1,225.9$ & 324.3 & 68.9 & 70.8 & 696.0 \\
\hline SYRIA & 556.4 & 947.3 & 900.0 & 120.8 & 12.8 & 90.2 & 17.8 & 165.6 \\
\hline TUNISIA & 409.8 & 611.7 & $2,507.7$ & 27.8 & 16.0 & 40.7 & 73.9 & 11.6 \\
\hline UAE & 315.7 & 465.8 & $1,671.8$ & 859.5 & 28.5 & 14.3 & 249.3 & 612.5 \\
\hline YEMEN & 3.1 & 406.1 & $3,597.3$ & 392.7 & 1.6 & 8.2 & 247.3 & 220.8 \\
\hline Total & $11,532.9$ & $12,314.5$ & $42,646.9$ & $4,388.0$ & 455.5 & 722.1 & $2,004.4$ & $3,012.9$ \\
\hline
\end{tabular}

464

Table 4 The ratio of saved water and lands to internal water resources and agricultural land area in the Arab World

\begin{tabular}{lrrrr}
\hline \multicolumn{1}{c}{ Importers } & $\begin{array}{c}\text { Internal water } \\
\text { resource* } \\
\left(10^{9} \mathrm{~m}^{3}\right)\end{array}$ & $\begin{array}{c}\text { National } \\
\text { blue water saving } \\
\left(10^{9} \mathrm{~m}^{3}\right)\end{array}$ & $\begin{array}{c}\text { Agricultural } \\
\text { land* } \\
(1000 \mathrm{ha})\end{array}$ & $\begin{array}{c}\text { National } \\
\text { land saving** } \\
(1000 \mathrm{ha})\end{array}$ \\
\hline ALGERIA & 11.25 & 0.56 & 41432 & 4902 \\
EGYPT & 1.80 & 13.05 & 3761 & 1964 \\
IRAQ & 35.20 & 12.17 & 9230 & 2398 \\
JORDAN & 0.68 & 1.02 & 1057 & 1531 \\
KUWAIT & - & 1.14 & 154 & 229 \\
LEBANON & 4.80 & 0.06 & 658 & 238 \\
LIBYA & 0.70 & 1.73 & 15355 & 1704 \\
MOROCCO & 29.00 & 5.39 & 30401 & 6001 \\
OMAN & 1.40 & 0.69 & 1469 & 100 \\
QATAR & 0.06 & 0.17 & 68 & 32 \\
SAUDI ARABIA & 2.40 & 8.14 & 173295 & 1501 \\
SYRIA & 7.13 & 2.36 & 13921 & 1417 \\
TUNISIA & 4.20 & 0.21 & 9943 & 387 \\
UAE & 0.15 & 0.82 & 382 & 1656 \\
YEMEN & 2.10 & 6.05 & 23546 & \\
\hline *WW & & & &
\end{tabular}

* World Bank 2014

** Land saving considered barley, maize, and wheat except for rice because of lack of data. 
Hydrol. Earth Syst. Sci. Discuss., https://doi.org/10.5194/hess-2018-4

Manuscript under review for journal Hydrol. Earth Syst. Sci.

Discussion started: 17 January 2018

(c) Author(s) 2018. CC BY 4.0 License.

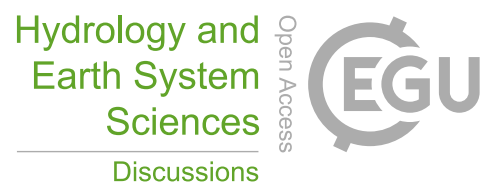

(c) (1)

470 Table 5 Water requirement for increasing $1 \%$ self-sufficiency of study crops in comparison with average self-sufficiency in 471 the Arab World from 2000 to 2012

\begin{tabular}{|c|c|c|c|c|c|c|}
\hline \multirow[t]{2}{*}{ Importers } & \multicolumn{3}{|c|}{$\begin{array}{c}\text { Average self-sufficiency from } 2000 \text { to } 2012 \\
(\%)\end{array}$} & \multicolumn{3}{|c|}{$\begin{array}{c}\text { Additional irrigation water requirement } \\
\qquad\left(10^{6} \mathrm{~m}^{3}\right)\end{array}$} \\
\hline & Barley & Maize & Wheat & Barley & Maize & Wheat \\
\hline$\overline{\text { ALGERIA }}$ & $81.77 \%$ & $0.05 \%$ & $30.13 \%$ & 5.88 & 1.74 & 7.27 \\
\hline EGYPT & $84.28 \%$ & $57.31 \%$ & $47.64 \%$ & 18.31 & 307.44 & 278.77 \\
\hline IRAQ & $95.55 \%$ & $94.18 \%$ & $44.12 \%$ & 983.99 & 122.93 & 233.96 \\
\hline JORDAN & $4.46 \%$ & $4.34 \%$ & $2.86 \%$ & 1.73 & 0.35 & 8.40 \\
\hline KUWAIT & $1.22 \%$ & $4.19 \%$ & $0.12 \%$ & 4.16 & 0.31 & 6.60 \\
\hline LEBANON & $33.63 \%$ & $1.22 \%$ & $25.65 \%$ & 0.00 & 0.04 & 0.65 \\
\hline LIBYA & $29.40 \%$ & $0.69 \%$ & $13.75 \%$ & 8.32 & 0.36 & 16.87 \\
\hline MOROCCO & $82.62 \%$ & $9.91 \%$ & $58.39 \%$ & 10.88 & 57.38 & 43.33 \\
\hline OMAN & $7.76 \%$ & $0.00 \%$ & $0.49 \%$ & 1.00 & 0.08 & 5.70 \\
\hline QATAR & $7.93 \%$ & $24.94 \%$ & $0.07 \%$ & 0.67 & 0.04 & 0.79 \\
\hline SAUDI ARABIA & $1.08 \%$ & $5.11 \%$ & $74.02 \%$ & 51.64 & 22.81 & 118.11 \\
\hline SYRIA & $67.54 \%$ & $13.83 \%$ & $89.81 \%$ & 1.60 & 28.28 & 213.67 \\
\hline TUNISIA & $50.27 \%$ & $0.00 \%$ & $46.05 \%$ & 1.26 & 0.61 & 3.84 \\
\hline UAE & $0.05 \%$ & $0.73 \%$ & $0.01 \%$ & 0.17 & 0.33 & 5.46 \\
\hline YEMEN & $91.49 \%$ & $14.28 \%$ & $7.64 \%$ & - & 13.98 & 58.54 \\
\hline
\end{tabular}

